\title{
Research as a means of empowering teachers in the 21st century
}

\author{
Hoy se evidencia una diversidad sorprendente y, a la vez, \\ estimulante de buscar y encontrar el conocimiento, darle \\ validez y cientificidad. Procesos que reclaman docentes \\ [...] interesados, no en repetir saberes, sino por el contrario, \\ docentes cuya labor esté íntimamente relacionada con \\ la construcción del conocimiento; en suma, docentes \\ dispuestos a aprender y desaprender para ser partícipes \\ del desarrollo de la ciencia al servicio del ser humano.
}

Isabel Hernández Arteaga (2009)

\author{
Yamith J. Fandiño \\ Magíster en docencia. \\ Docente, Facultad de Ciencias y Educación, \\ Universidad Distrital Francisco José de Caldas, \\ Bogotá, D. C., Colombia. \\ Docente, Facultad de Educación, Universidad de \\ La Salle, Bogotá, D. C., Colombia. \\ teacheryamith@gmail.com
}

\begin{abstract}
The article proposes action research as a legitimate way to develop and empower teachers to be active knowers and critical agents who are capable of undertaking innovative action to transform their practices and circumstances as educators. It begins by considering the development and empowerment of teachers as intentional processes that allow teachers not only to question and resist means of regulation and control, but also to take command of their own lives in a way that enables them to develop their professional skills. It goes on to show how teachers can construct a personal and contextual theory of education or pedagogical know-how by systematically researching their teaching practices and classroom situations. Finally, it looks at what action research is, explains the different types and stages of action research, shows how it has been used in Colombia and proposes possible research problems and the types of empowerment that can result from them. The article ends by stating that teachers should resort to action research not only to gain and wield power, but also to make way for self-development and professional growth.
\end{abstract}

\section{Key words}

Education action research, education research, teaching practice, professional training, innovation in education (Source: UNESCO Thesaurus).

Recibido: 2009-07-15 | Aceptado: 2010-03-25

ISSN 0123-1294 | Educ.Educ. Vol. 13, No. 1 | Abril 2010 | pp. 109-124 


\section{La investigación como medio de empoderamiento de los profesores en el siglo XXI}

\section{Resumen}

Se busca proponer la investigación, la investigación acción en concreto, como una forma legítima para desarrollar y empoderar a los profesores para que, como conocedores activos y agentes críticos, puedan iniciar acciones innovadoras para transformar sus prácticas y realidades educativas, lo que les permitirá construir su propio saber pedagógico. Se empieza considerando el desarrollo y el empoderamiento docente como procesos intencionales que les permiten a los profesores no sólo cuestionar y resistir mecanismos de regulación y control sino tomar las riendas de sus vidas para desarrollar sus competencias profesionales. Luego, se muestra cómo ellos pueden construir una teoría educativa o saber pedagógico personal y contextual al investigar sus prácticas docentes y realidades de aula. Por último, se analiza la investigación acción, se explican sus tipos y etapas, se presenta cómo se ha usado en Colombia y se proponen posibles problemas de investigación $y$ los tipos de empoderamientos que de ellos pueden surgir. Se concluye con la afirmación de que los profesores deberían recurrir a la investigación acción no sólo para ganar y ejercer poder sino para abrir espacios para el autodesarrollo y el crecimiento profesional.

Palabras clave

Docencia, práctica pedagógica, formación profesional, innovación educacional, investigación (Fuente: Tesauro de la Unesco).

\section{Pesquisa como forma de empoderamento de professores no século XXI}

\section{Resumo}

Estetrabalhopropõea pesquisa-açãocomoumaformalegitima de desenvolver e empoderar aos professores para que, como agentes ativos e conhecedores críticos, possam tomar medidas innovadoras para transformar suas práticas e realidades educacionais. Começa a considerar o desenvolvimento e o empoderamento de professores como um processo intencional que lhes permite não só desafiar e resistir uma regulação e os mecanismos de controle, mas também dirigir suas vidas para desenvolver suas habilidades profissionais. Em seguida, mostra como os professores podem construir uma teoria educacional ou conhecimento pedagógico pessoal e contextual ao pesquisar sistematicamente suas práticas docentes e as realidades da sala de aula. Finalmente, discute-se que é pesquisa-ação, explicam-se seus tipos e fases, mostra-se como tem sido utilizada na Colômbia e sugerem-se possiveis problemas de pesquisa e os tipos de empoderamento que possam surgir dela. $O$ artigo conclui afirmando que os professores deveriam utilizar a pesquisaação não só para adquirir e exercer o poder, mas também para criar oportunidades de auto-desenvolvimento e crescimento profissional.

\section{Palavras-chave}

Pesquisa-ação educacional, pesquisa educacional, prática pedagógica, formação profissional, inovação educacional (Fonte: Tesouro da Unesco). 


\section{Introduction}

The twenty-first century has brought sweeping changes in education. On the one hand, the increasing globalization and everchanging dynamics of the modern world demand the formation of a new type of professional, one who is capable of dealing with the unexpected and the complex. On the other hand, the ongoing debate and the intellectual inquiries of the academic world have set forth the reasons for developing better educational systems, specifically in the sense of frameworks designed to favour creativity and questioning. As a result, many countries have engaged in a series of educational reforms with respect to infrastructure, curriculum, methods and evaluation.

One of the key elements in most educational reform is the teacher. Societies are finally understanding, as stated by Eleonora Villegas-Reimers (2003, p. 7), that the teacher is not just one of the variables that must be changed if their educational systems are to be improved. Societies are realizing the teacher is also one of the most significant agents of change in such reforms. For VillegasReimers, this dual role - being both the subject and the object of change - makes the field of teacher development a challenging area, one that has received major attention in past years.

Societies and educational institutions expect a great deal from their teachers ${ }^{1}$. Teachers are expected to respond adequately to the pressing demands of the modern world and to the growing concerns of the educational community. They also are expected to be highly professional and to have considerable expertise, so as to guarantee qualified and successful educational processes and practices. Consequently, more and more teachers are opting to participate in on-the-job training, training courses and postgraduate education in order to grow professionally and to develop as teachers. But, what exactly is teacher development? The following section deals with that topic.

\section{Teacher Development}

Broadly speaking, teacher development is the professional growth a teacher achieves by gaining added experience and by methodically examining his or her teaching. It is a long-term process that includes routine opportunities and systematic experiences planned to foster growth and development in the teaching profession. It is broader than career development, which is the growth that results from moving through the professional career cycle, and broader than staff development, which involves the provision of organized in-service programmes (Glatthorn, 1995, p. 41, cited in Villegas-Reimers, 2003, p. 11).

With regard to professional development, Ingvarson (1998) contrasts a traditional system, identifying it as in-service training with goals established by governments and employers, with a standard-base system where professional bodies decide on goals and models. Cochran-Smith and Lytle (2001, p. 47) described three systems of professional development that coexist in the educational world and are used to explain and justify different approaches to improving teaching and learning. They are: knowledge-for-practice (formal theory generated by university-based researchers and used by teachers to improve their practice), knowledge-in-practice (practical knowledge that is embedded in practice), and knowledge-of-practice (reflective knowledge that emerges when teachers ponder their practice).

Robison Acosta Roa (2006) is of the opinion that teacher development must reflect on pedagogical, epistemological, historical and social elements if they are to interpret the changes that mankind has undergone. To do so, as explained by Acosta Roa, teachers need to develop their capacity for proposing innovative strategies and to strengthen their skill for intervening in the transformation of education. Teacher development, then, should centre on creating methods designed to bring together disciplinary and investigative relations that are conducive to the formation of upright and well-around teachers. Acosta Roa believes teacher development is intended to help teachers attain a critical comprehension of what to teach, how to teach and why.

1 In ¿Qué espera la sociedad colombiana de los profesores de lenguas extranjeras?, Ligia Cortés, Jairo Hernández, \& Rafael Arteaga Díaz (2008) state that EFL teachers are expected to extend their conceptual horizon, to qualify their teaching practice and basic expertise, and to foster in students an awareness of a diverse world made up of different cultures and world views. 
Nevertheless, the premise that permeates this article is the belief that teachers are not supposed to develop professionally to meet the demands of today's society and to address the concerns of the educational system but, more importantly, to take control of their own lives and to develop their professional competence. Here, I concur with Jack Whitehead (1989) who views professional development not as the development of a technical/propositional teaching experience (encyclopaedic knowledge applied in teaching practice to achieve predetermined results) or merely as the development of a reflective/critical philosophy of teaching (reflection used in educational practice to bring into play a critique and transformation of sociocultural contexts), ${ }^{2}$ but as the construction of a living educational theory (a living form of question and answer to view your own life and work; that is, a living enquiry conducted by oneself to ask why one is the way one is and why one does the things one does ${ }^{3}$ ).

Jack Whitehead (1989) says teachers can, and should, develop professionally by entering into a critical and systematic inner dialogue to understand their own practices and circumstances. Teacher development, therefore, needs to shift from propositional forms of theory that deal with facts to dialectic forms of theory that show how people explain their actions in terms of their own values and intentions. Consequently, I understand teacher development as a process of self-discovery, updating and fulfilment in which teachers are active knowers who are responsible for expounding their insights about the nature of their professional lives and critical agents who are capable of acting on that knowledge to transform their practices and circumstances. For me, teacher development is a process of selfexamination that helps teachers to become dynamic knowers and analytical agents who are capable of realizing and understanding how and why they do what they do and are committed to sharing and communicating their findings and conclusions to others. It is, therefore, a process that must provide teachers with empowerment and pedagogic know-how. The following sections elaborate on that idea.

\section{Empowerment}

Nanette Page and Cheryl E. Czuba's (1999) literature review of articles with a focus on empowerment resulted in no clear definition of the concept across disciplinary lines. They found that many who used the term cope with its lack of a clear, shared meaning by emplo- ying the concept in a very narrow sense, and using only their specific scholarly discipline or program to inform them. Others did not define the term at all. As a result, Page and Czuba concluded that many had come to view empowerment as nothing more than a popular buzz word to be thrown in to make sure old programs get new funding.

Page and Czuba (Op. cit., p. 3) claim that empowerment is a multi-dimensional social process that helps people to gain control over their own lives and society, by acting on issues they define as important. It is multi-dimensional in that it occurs within sociological, psychological, economic and other dimensions at various levels (e.g. individual, group and community). Empowerment is social, since it occurs in relation to others. Empowerment is a process, because it is similar to a path or journey, one that develops as people walk through it. For Page and Czuba, at the core of the concept of empowerment is the idea of power, understood not merely as domination, authority, control or influence, but also as a process of change within the context of a relationship between people or things.

Alfonso Sánchez Pilonieta (2002) explains that empowerment, as a construct, refers to the development or increase of power for (a means of or vehicle for action, generation or accomplishment) and expansion of the capacity of a person or group to question and resist power over (a mechanism for domination, obedience and submission). In his opinion, empowerment seeks a close tie between the constitution of the subject and the psychosocial ways of exercising power. Consequently, he defines empowerment as an ongoing, intersubjective, and intentional process of converting individuals into subjects who are conscious of themselves and their social circumstances, through comprehensive, critical and transformative action on their own social interactions.

2 See Contreras's (2001) discussion on teacher autonomy via three types of teachers: the expert technician, the reflexive professional, and the intellectual critic.

3 Based on Whitehead, Jean McNiff (2002), who explained teachers' professional development as a self-reflective practice carried out through practitioner-based action research. 
Following Foucault, Sánchez Pilonieta says the intentional process of converting individuals into conscious subjects is comprised of two moments. The first involves self-discovery of external chains and one's own limitations, as well as the potential of one's community and one's right to search for a better future. The second moment consists of the exercise of social and political action that gradually permits the transformations required for development as a free individual and member of a community. Therefore, empowerment demands a political and collective transformation that breaks the prevailing dominance, so those who have been excluded or silenced can come into being.

One way to achieve such a radical transformation is narration. According to Sánchez Pilonieta, through narrative action, what is instituted is reaffirmed, what has not been taken into account can become the foreground, and vice versa. Narration allows for listening to people's stories and amplifying and valuing them in ways that allow people to discover those stories and to create new ones. It can be used to change a person's position in the world, since those who dominate can lose or hand over their rank and those who were dominated can act and be heard. Accordingly, narration can be a basic strategy for approaching the practice and understanding of empowerment, because it promotes processes whereby people can discover, believe and publicize collective narratives containing their own story, a process free of the predominant discourse and capable of achieving personal and social change.

Pursuant to Page, Czuba and Sánchez Pilonieta, I understand empowerment as a multi-dimensional social process that helps individuals to gain and exercise power over their own lives, practices and circumstances. It is an ongoing and intentional process in which people become aware of themselves, their sociocultural milieu and contextual factors. As a result, not only can they question and resist mechanisms of regulation, domination and control, they also can undertake critical and transformative actions to generate better sociocultural interactions and to accomplish personal and/or professional objectives. Basically, empowerment is obtained when one can generate a personal and social narrative that distances itself from the dominant discourse, a narrative that allows one to construct one's own discourse. ${ }^{4}$ Therefore, empowerment can first be gained when one has the possibility of discovering and creating one's own "voice". ${ }^{5}$ For me, in the case of teachers, the concept of voice is linked inherently to the construction of their living educational theory; that is, the structuring of their pedagogical know-how. I will come back to this point later, but first let me discuss teacher empowerment in some detail.

\section{Teacher Empowerment}

Bruce Romanish (1993) maintains the meaning of teacher empowerment should be considered before anyone can state that teachers are on the road to a broader voice in educational affairs. He argues against understanding it as simple actions to increase teacher knowledge, because enhanced teacher preparation does not translate directly into increased influence over the decisions that affect their capacity to teach. Nor does improving the teacher's knowledge challenge the top-down hierarchical structure of the status quo in which teachers are merely the means through which the system exercises its will in the classroom.

Instead, Romanish argues for an understanding of teacher empowerment as validating the role and authority of the teacher's experience in ways that enable teachers to overcome the barriers to effective practice that their daily experiences deemed as necessary. This understanding also demands that schools be regarded as sites for the creation of democratic understanding and sympathies that guarantee teachers' decision-making authority and increased power.

4 Here, I do not understand discourse within linguistics (language or linguistic structures above the level of the sentence) or within discourse analysis (those elements that are viewed as rule-governed and systematic, but do not occur at the level of the word or the phrase). Rather, $\mathrm{I}$ am in favour of regarding it as the space and process where intersubjectivity is established, objects of knowledge are produced, and values are assigned (See Bahktin, 1986, Speech Genres and Other Later Essays). I also find Foucault's view of discourse very useful: discourse is the system of thought composed of ideas, attitudes, courses of action, beliefs and practices that systematically construct the subjects and the worlds of which they speak (See Foucault, 1972, Archaeology of Knowledge).

In "Teacher Voice: How is it Shaped?", Claudia Yolanda Becerra Camargo (2005) claims the concept of voice deals with gaining the agency to express one's life and with developing one's possibilities to articulate alternative realities. For her, voice not only represents the kind of values, beliefs, ideologies and structuring principles one has; it also is shaped by other factors and other internal and external voices. With regard to the teacher's voice, she considers it important to take into account political relations of power, government policies and the inner voice and the curricular choices teachers make. 
Thus, for Romanish, teacher empowerment revolves around helping teachers to become central shapers of the educational enterprise by validating their experience, decision-making authority and power, and, ultimately, by making sure they have a genuine say in school practices and circumstances.

Paula M. Short (1994), in concurrence with Zimmerman and Rappaport (1988), regards it as a construct that ties teachers' personal competence and ability to educational environments that provide opportunities for a choice in demonstrating that competence. On the one hand, teachers believe they have the skills and knowledge to act on a situation and to improve it. On the other hand, schools create opportunities for competence to be developed and displayed. For Short, teacher empowerment is a process whereby school participants develop the competence to take charge of their own growth and to resolve their own problems, while school systems increase the capacity to distribute roles in decisionmaking and to increase opportunities for meaningful, collective participation.

According to M. Short, there are six dimensions of teacher empowerment:

- Professional development: Teachers' belief that the schools where they work provide them with opportunities to grow and develop professionally, to learn continuously and to expand their own skills through the work of the school.

- Autonomy: Teachers' confidence in the sense of freedom to make decisions and to control aspects of their work life. ${ }^{6}$

- Involvement in decision making: Teachers' participation in and responsibility for critical decision-making that directly affects their work: budgets, teacher selection, scheduling, curriculum and other programmatic areas.

- Teacher impact: Teachers' perception that they have an impact and influence on school life.

- Teacher status: Teachers' belief that others truly respect their professional knowledge and that they have the genuine support of their colleagues.

- Teacher self-efficacy: Teachers' perception that they have the skills to help students learn and are competent in building effective programs to institute positive changes in student learning.

In "Innovar e investigar: Dos modos de visibilizar el posicionamiento y empoderamiento del docente," María Cristina Martínez
Pineda (2008) maintains that teacher empowerment can become visible through research and innovation, because assuming educational practice as an object of reflection produces an effect on the subjectivity of teachers that increase their capacity for analysis, observation and insight. Consistency and strength in innovation and research empower teachers, since these activities position them as professionals who can produce knowledge of education and exercise power over it. According to Martínez Pineda, not only does assuming research and innovation rigorously help teachers to develop attitudes towards inquiry, criticism and communication, it also and, more importantly, helps them to construct pedagogical know-how, which ultimately produces a transformation of practices and subjects. Thus, teacher empowerment enables teachers to be subjects of knowledge who are recognized, requested and followed by others, a situation that facilitates the emergence or strengthening of collectives, groups and networks of teachers.

Taking into account Romanish, Short and Martínez Pineda's views, I understand teacher empowerment as a process whereby teachers develop, increase and validate their experience, decision-making, and authority in order to have an effective say in their educational practices and circumstances. It is based on schools' commitment to sharing decision-making roles, to creating room for significant collaborative participation, and to ensuring the creation of democratic understanding. Teacher empowerment helps teachers to exercise power over their educational lives, to resist control mechanisms and to transform the educational system, which ultimately challenges the top-down hierarchical structure of the educational status quo. Through research and innovation, teacher empowerment can help teachers to generate and amplify their voice or discourse on educational affairs, to build their living educational theory, and to construct their pedagogical know-how.

6 For a thorough discussion of teacher autonomy, see Usma (2007). 
Here, the point I am trying to make is that, if teachers are to be empowered, they need to be able to exercise control over their own educational lives, to gain the agency to realize and understand how and why they do what they do, to have the competence to achieve personal and social transformation, to become dynamic knowers and analytical agents of their educational contexts, and to create their own narratives free from dominant discourse. In brief, if teachers are to be empowered, they need to be able to discover their own voice, to construct their own living educational theory and to construct their pedagogical know-how.

\section{The Construction of Pedagogical Know-how}

According to Bernando Restrepo Gómez (2004), there is no consensus on what pedagogy is, neither is there a consensus on what pedagogical know-how is. Nevertheless, when the latter is mentioned, there is an allusion to practical professional knowledge that deals with formalization of the pedagogical know-how constructed by individual teachers. For Restrepo Gómez, pedagogical know-how is the adaptation of pedagogical theories to professional practice, in accordance with the particular circumstances of the teacher's personality and the setting in which he/she acts. It is more individual and personal. It is related closely to the competence needed for effective practice and, although it is based on pedagogical theories, it often is obliged to distance itself from the official pedagogical discourse.

The construction of pedagogical know-how, says Bernando Romero, involves a continuous dialogue between theory and practice. In this dialogue, pedagogical adaptation deals with the disciplinary and pedagogical spheres. The disciplinary sphere includes declarative and procedural knowledge of the discipline being taught. The pedagogical sphere, on the other hand, involves research and the construction of know-how that allows students to assimilate a discipline and to interiorize attitudes and values.

Besides facilitating a dialogue between theory and practice, the construction of pedagogical know-how allows teachers to pass from empirical/practical doing to reflective/critical practice. Initially, they do so when they weave their daily pedagogical work in an effort to respond adequately to the conditions of their working environment and to the learning needs and sociocultural agenda of their students. Yet, for the most part, they do so through reflection on their actions, reflection that takes teachers from applying learned pedagogical discourse to creating pedagogical know-how, specifically know-how that enables them to criticize and transform their practice and reality. ${ }^{7}$

In a similar vein, Gloria Calvo (2003) states that teachers' know-how is professional knowledge that emerges from practice. It is pragmatic knowledge linked to teachers' profession, duties and everyday life, knowledge that leads to professional competence. It can be legitimized through reflective and democratic studies on the construction and reconstruction of educational practice. Therefore, teachers need to recognize and use their capacity to produce theory based on the daily actions and practices they implement in their classrooms and educational institutions. For Calvo, teachers need to realize they can write about their practice, they can ask research questions, they can generate knowledge and they can give and receive feedback on educational matters. In short, teachers' capacity to understand their professional behaviour can be qualified, developed and enhanced through systematic and profound research studies, which eventually can favour the creation of a critical professional culture founded on analysis, confrontation and transformation.

Based on the preceding sections, it seems reasonable to assume that the construction of teachers' pedagogical know-how through research can help to develop and empower teachers, because they can construct their own living educational theory and find or enhance their voice in the educational system. To recapitulate, research can:

- help teachers embark on a process of self-discovery, updating and fulfilment as

7 Bernando Restrepo Gomez (2003) maintains that teachers need research if they want to systematize and consolidate their know-how. For him, research in general and educational action research in particular allow teachers to behave as long-life learners, since research teaches them how to learn to learn, how to understand the structure of their own practice and how to transform their pedagogical practice permanently and systematically. 
active knowers responsible for elucidating the nature of their professional lives and critical agents capable of acting on that knowledge to transform their practices and circumstances (teacher development);

- $\quad$ enable teachers to generate a personal and social narrative that distances itself from the dominant discourse and allows them not only to resist mechanisms of submission and control, but also to undertake critical and transformative actions to accomplish personal and/or professional objectives (empowerment);

- $\quad$ aid teachers in developing, increasing and validating their experience, decision-making, authority and power in order to have a voice/discourse on their educational practices and the educational circumstances of their schools, which ultimately prepares them to accomplish social transformation/improvement (teacher empowerment); and

- allow teachers to have a constructive dialogue between theory and practice and to pass from empirical/practical doing to reflective/critical action, which permits them to systematize and consolidate their educational practice, discourse and knowledge (construction of pedagogical know-how).

Research, then, seems to be a key element in a teacher's development and empowerment. But, in education, what is research? How should it be done? The following sections focus on conducting research on education.

\section{Teacher Research}

According to Virginia LoCastro (2000, p.1), when seeing or hearing the phrase "teachers as researchers" most classroom practitioners dismiss the idea as something they might do in the future, but for which they have no time at present. Teachers also feel less than confident with the notion of "research," as they may believe they lack the training to carry out classroom research (CR). These reactions, explains LoCastro, seemed understandable, since they derive from traditional generalizations and beliefs about what research is and how it should be done.

However, Bernando Restrepo Gómez (2000) says that teachers, in fact, can do research when they submit their daily practice to rigorous self-examination in order to respond adequately to their working environment and to the needs and social agenda of their students. In his opinion, teachers can use retrospection, introspection and participatory observation to clarify guiding theories and to specify pedagogical interventions in order to resignify and transform unsuccessful practices. If done systematically and con- sistently, Restrepo maintains teachers' empirical doing can become a reflective practice.

In 1975, Stenhouse called for educational research centred on educational processes and done by teachers. His student and collaborator, John Elliot, continued this line of inquiry and published a book on action research in education (1994) to develop that proposal. According to Stenhouse and Elliot (1993, 1994), teaching should not be an activity done by teachers and research on teaching should not be a separate activity conducted by outside researchers. For them, the practice of teaching should be regarded as a reflective activity, which would dispel the division between teachers and researchers. In other words, teaching and research should be assumed as an integrated action on the part of educational practitioners.

Based on the foregoing theoretical appraisals, I argue in favour of regarding teachers as researchers who should permanently submit their daily practice to rigorous self-examination in order to overcome their repetitive routine and to transform their teaching practices and circumstances. At the heart of teachers' research endeavours, there should be a focus on critical inquiry into their own practice. In other words, teachers should use research to think about their own contexts, to analyze their judgments and interpretations and to distance themselves in order to open the basis of their work to inspection (Finch, 2005). However, an obvious question arises: how can teachers use research in their classrooms? The following sections will discuss classroom research and action research in detail.

\section{Classroom Research}

Daniel Madrid (2000, p. 2-3) indicates that classroom research (CR) is normally practical research, which is centred on the classroom. It aims to explain what actually happens inside the classroom, the direct and indirect influence of internal and external factors related to the student, the teacher and the ELT curriculum. As Van 
Lier $(1988$, p. 7) points out, we know very little about what goes on in classrooms. Accordingly, classroom research becomes an important tool to explain the relationship between the diversity of variables that continuously interact.

According to Nunan (1989, p. 15), CR can shed light on the interaction between two of the most important variables in classrooms: teachers and learners. However, it can do so from two different, but complementary perspectives. On the one hand, teacher-focused CR can examine factors such as the classroom decision-making processes of teachers and what is referred to as "teacher talk". On the other hand, research focused on the learner can examine the developmental aspects of learners' processes or the learning styles and strategies used by different learners. It also can analyze the type of communication prompted by various types of materials and pedagogic tasks, the classroom interaction that takes place between learners and the effect of that interaction on learner development.

Melba Libia Cardenas (2000) explains that classroom research has become a medium to promote critical thinking about our own teaching practices and to evaluate, change and grow professionally. Citing Allright and Bailey (1981), she states that CR can be directed towards trying to understand and deal with the immediate practical problems facing teachers and learners. Such problems and initial research can provide a starting point for highly specific classroom exploration. For Cardenas, regardless of the approach used in classroom research, it is important to afford it relevance within the teaching-learning process, so it not only improves one classroom or one school in particular, but the entire educational system. One way to do so is action research (AR).

\section{Action Research}

In literature, the definition of action research has been provided by many scholars:

$A R$ is the reflective process whereby, in a given problem area where one wishes to improve practice or personal understanding, inquiry is carried out by the practitioner --; first, to clearly define the problem; secondly, to specify a plan of action --; including the testing of hypotheses by application of action to the problem. Evaluation is then undertaken to monitor and establish the effectiveness of the actions taken. Finally, participants reflect upon, explain developments and communicate those results to the community of action researchers. AR is systematic self-reflective inquiry by practitioners to improve practice." (McKernan, 1996)

$A R$ is a term which refers to a practical way of looking at your own work to check that it is as you would like it to be... it is often referred to as practitioner based research; and because it involves you thinking about and reflecting on your work, it can also be called a form of self-reflective practice... In action research, researchers do research on themselves... AR is an enquiry conducted by the self into the self. You, a practitioner, think about your own life and work, and this involves you asking yourself why you do the things that you do, and why you are the way that you are. (McNiff, 2002)

It seems possible to argue that AR is studying what is happening in our classroom and deciding how to make it a better place by changing what and how we teach and how we relate to students and the community. Teachers-researchers study a problem systematically and consistently, ensuring the intervention is informed by theoretical considerations. For its capability to raise awareness, Rory O'Brien (2001) situates AR in a specific research paradigm: the paradigm of praxis. ${ }^{8}$ He maintains that by sharing a number of perspectives with the interpretive paradigm, and making considerable use of its related qualitative methodologies, neither it nor the positivist paradigms are sufficient epistemological structures in which to place action research. Rather, a paradigm of praxis is where the main affinities lie, because - for O'Brien - a cornerstone of AR is that knowledge is derived from practice and practice informed by knowledge as part of an ongoing process.

\section{Types of Action Research}

There are several varieties of action research. James McKernan (1996, p. 16-27), for example, identified the three following types of

8 Praxis, a term used by Aristotle, is the art of acting upon the conditions one faces in order to change them. 
Table 1. Types of AR

\begin{tabular}{|c|c|c|}
\hline $\begin{array}{l}\text { Scientific-technical view of } \\
\text { problem solving }\end{array}$ & $\begin{array}{l}\text { Practical-deliberative action } \\
\text { research }\end{array}$ & $\begin{array}{l}\text { Critical-emancipatory action } \\
\text { research }\end{array}$ \\
\hline $\begin{array}{l}\text { The fundamental goal of the re- } \\
\text { searcher is to test a particular } \\
\text { intervention used by a practitio- } \\
\text { ner in the field. The researcher } \\
\text { identifies the problem and a spe- } \\
\text { cific intervention and, then, the } \\
\text { practitioner becomes involved } \\
\text { in implementing the intervention } \\
\text { or treatment. This approach to } \\
\text { AR results in the accumulation of } \\
\text { predictive knowledge. The major } \\
\text { thrust is the validation and refi- } \\
\text { nement of existing theories. }\end{array}$ & $\begin{array}{l}\text { The goal of practical AR is to un- } \\
\text { derstand practice and to solve } \\
\text { immediate problems. With the } \\
\text { practical-deliberative type of AR, } \\
\text { the researcher and practitioners } \\
\text { come together to identify poten- } \\
\text { tial problems, their underlying } \\
\text { causes and possible interventions. } \\
\text { Practical AR fosters improve- } \\
\text { ments in professional practices } \\
\text { by emphasising the part played by } \\
\text { personal judgement in decisions } \\
\text { to act. }\end{array}$ & $\begin{array}{l}\text { There are two goals for the re- } \\
\text { searcher who uses this approach. } \\
\text { One is to increase the proximi- } \\
\text { ty between the actual problems } \\
\text { encountered by practitioners and } \\
\text { the theory used to explain and re- } \\
\text { solve them. The second goal is to } \\
\text { assist practitioners in identifying } \\
\text { the fundamental problems by rai- } \\
\text { sing their collective awareness. } \\
\text { Critical-emancipatory AR pro- } \\
\text { motes a critical awareness, which } \\
\text { exhibits itself in policy and prac- } \\
\text { tical action to promote change. }\end{array}$ \\
\hline
\end{tabular}

AR: a scientific-technical view of problem solving, practical-deliberative action research and critical-emancipatory action research. These types of AR are explained in the following table.

\section{Stages in Action Research}

A variety of procedural plans have been developed by different scholars. All adopt methodical and interactive research sequen- ces to systematically introduce innovations in teaching and learning. Also, these sequences or stages strive to bring theory and practice together. In other words, they seek to put the teacher in the role of a producer of educational theory and a user of that theory. The following table offers an overview of several AR models.

Table 2. Stages in AR

\begin{tabular}{|c|c|c|c|}
\hline STAGE & McKernan (1996) & Anne Burns (1999) & Jean McNiff (2002) \\
\hline 1 & $\begin{array}{l}\text { Definition or determination of } \\
\text { the issue or problem. }\end{array}$ & Exploring & Review current practice. \\
\hline 2 & Needs assessment & Identifying & $\begin{array}{l}\text { Identify an aspect to investi- } \\
\text { gate. }\end{array}$ \\
\hline 3 & Hypothesis, ideas. & Planning & Imagine a way forward. \\
\hline 4 & Develop an action plan. & Collecting data & Try it out. \\
\hline 5 & $\begin{array}{l}\text { Implement and monitor the } \\
\text { action plan. }\end{array}$ & Analysing / Reflecting & Take stock of what happens. \\
\hline 6 & Evaluate monitoring data. & $\begin{array}{l}\text { Hypothesising / Specula- } \\
\text { ting }\end{array}$ & $\begin{array}{l}\text { Modify what is being done and } \\
\text { continue working in this new } \\
\text { way. }\end{array}$ \\
\hline
\end{tabular}




\begin{tabular}{|c|l|l|l|}
\hline STAGE & McKernan (1996) & Anne Burns (1999) & Jean McNiff (2002) \\
\hline 7 & $\begin{array}{l}\text { Reflect on, explain or unders- } \\
\text { tand in light of the data. }\end{array}$ & Intervening & Monitor what is done. \\
\hline 8 & Make decisions. & Observing & $\begin{array}{l}\text { Review and evaluate the mo- } \\
\text { dified action. }\end{array}$ \\
\hline 9 & $\begin{array}{l}\text { Redefine the issue or pro- } \\
\text { blem. }\end{array}$ & $\begin{array}{l}\text { Reporting, writing and pre- } \\
\text { senting }\end{array}$ & \\
\hline
\end{tabular}

As shown in the foregoing table, AR embraces problem identification, action planning, implementation, evaluation and reflection. It involves a spiral of steps, beginning with identification of the problem area. Then, the scope of the problem is narrowed down to make it manageable. Through research (e.g. observation, interviews, surveys, recording, etc.), the teacher identifies when the problem occurs, what affects it, what causes it, etc. To suggest a solution, talking with other teachers and/or reading is needed, and the researcher considers what evidence to collect so as to decide whether his/her action is successful or not. Later, the hypothetical solution is implemented, and evidence to be analyzed is gathered to decide whether the aim is achieved or not. After the analysis, reflection identifies the results of the research and whether or not the problem has been solved. If not, the next step is to begin a new research cycle. However, if the results point to positive improvements, it is important to circulate the research, not so much in terms of the findings, but as research orientation towards teaching (Sarac-Suzer, 2007).

\section{Action Research in Colombia}

Cristina Frodden (1999) says the promotion of AR was necessary because teachers' involvement in research on their own classrooms was an effective way to tackle the conflict between theory and practice, and to enhance teachers' professional development. In her study on using collaborative AR in a graduate program for EFL teachers, she found that collaboration, time management, and student and teacher growth were enhanced. She concluded that researching and reflecting helps teachers to discover there are many skills that need to be developed, but are usually taken for granted.

Ciro Parra Moreno (2002) opted to adopt AR as a useful research method because he did not want to assume research as a simple methodological technique or to reduce his role as a teacher to that of an instructor who follows a series of didactic procedures predetermined by educational researchers. He regarded $\mathrm{AR}$ as an effective way for teachers to develop professionally and for the interpretation of educational knowledge as practical know-how. He characterized AR as focusing on an analysis of human actions and educational situations, striving to deepen teachers' understanding about their everyday problems, aiming to improve and change circumstances and, ultimately, dealing with the stimulation of teachers' reflection.

Josefina Quintero, Raúl Munevar, and Juan Carlos Yepes (2007) say that curricular change and teachers' professional development are related directly to AR. For them, AR helps teachers to act autonomously and to propose, experiment, take decisions and promote educational transformation with enthusiasm and satisfaction. They explain that curriculum quality can be achieved through AR, because it is teachers who are better positioned to make changes and innovations in settings that require ongoing improvement. In short, AR on the curriculum constitutes an effective way to re-negotiate consciously and to transform reflectively educational interactions and regulations.

Based on the foregoing theoretical considerations, it seems feasible to state that teaching should involve research and research should lead to teachers' learning; learning new things about their educational practices and circumstances, 
their personal strengths and weaknesses, and their professional challenges and opportunities. Undoubtedly, research can help to empower teachers, since it allows them to engage in critical reflection about what teaching and learning are, why certain actions are successful or not in the classroom, and, ultimately, how valid and justifiable their pedagogical know-how is. Preferably, teachers should strive to conduct research not simply to create new or improved activities, materials or procedures, but to bring to light the rationale behind those activities, materials or procedures because, as Bernard Dufeu (1994, p. 11) put it, "We do not leave our personal attitudes and preoccupations behind when we enter our professional world. Our teaching reflects who we are."

\section{Possible Action Research Problems and Types of Empowerment for Colombian Teachers}

It seems reasonable to claim that research is not merely an expectation of today's society or a requirement of current education, but an opportunity and a possibility in teachers' lives to understand who they are as professionals, to generate pedagogical knowledge based on their everyday practices, and to challenge and transform the educational status quo. But, what sort of action research problems can Colombian teachers tackle? And, more importantly, what kind of empowerment can they achieve through action research? I will briefly propose three main research problems that Colombian teachers should address. In time, doing so can produce three types of empowerment.

Josefina Quintero, Carmen T. Zulia and Odilia Ramírez (2005) indicate that teachers should pursue action research to exploit the new perspectives of education derived from the development of science, technology, society, culture and pedagogy to contend with the new systems of education, which expect teachers to construct an integrated body of pedagogical knowledge, and to meet the new expectations of education based on an identification of what it means personally to improve and qualify teachers' action. More concretely, Omaira Vergara Luján, Fanny Hernández Gaviria and Rosalba Cárdenas Ramos (2009) assert that Colombian teachers should do educational research to be able to:

- develop a positive and decisive attitude towards making research processes a part of their daily work and professional development;

- develop a capacity to reflect on and evaluate their own academic processes and those of their colleagues and students in a constructive light;
- develop a good level of knowledge and competence in their field, not only with respect to content but also pedagogic knowledge; and

- develop tools to build a strong cultural and professional identity manifest in their role as agents of social change.

These authors present a broad range of possibilities through which teachers can find problems, issues, concerns and dilemmas to which action research can be applied. However, I believe Colombian teachers should observe, describe, interpret, reflect, question and act on problems that emerge in their lives as teachers, in their immediate communities (classrooms and schools), and in their global societies (city, country, academic field). In other words, Colombian teachers should use research, specifically action research, to investigate three basic types of problems: personal problems derived from their role as educators (decision-making process, teacher talk, use of ICTs, types of assessment, etc.), communal problems that result from being part of a particular classroom and school (students' fear of speaking, learners' use of learning strategies, curriculum development, syllabus design, etc.), and social problems attributed to being citizens of a specific city or country and agents of an academic field (educational inequalities, value system, cultural practices, knowledge creation, professional competences, etc.). Here, the point I am trying to make is that the person, the community and society are the areas or dimensions that provide Colombian teachers with the basic problems they should research.

Consequently, it is worth mentioning that personal, communal and social problems can allow for three types of empowerment: individual, collective and social. As Page and Czuba (Op. cit.) explain, this is because empowerment is a process that fosters power (that is, the capacity to wield it) in people for use in their own lives, their communities and their societies. Individual empowerment will help teachers to become subjects who are fully conscious of themselves, their strengths, their circumstances and their possibilities. Collective empowerment will help 
teachers to be agents who are capable of critical and transformative action in their social interactions with students and other teachers. Social empowerment will position teachers as professionals who can produce knowledge about education and exercise power over society. In other words, empowerment can enable teachers to become "powerful" subjects, agents and professionals who are prepared to solve the complex issues facing education in a creative and realistic way.

\section{Conclusion}

Today, the teacher's role is changing rapidly from a traditional perspective to a modern one. Instead of being followers of new methodologies, teachers are supposed to be the author and source of the theoretical basis for their own practices; they are supposed to be researchers within the territory of their own classroom and/or institution (Sarac-Suzer, Op. cit.). Therefore, teachers should know and feel they are the practitioners and theorists of modern-day educational systems. Observing and investigating their practices systematically and understanding and transforming their circumstances critically are fundamental and irrefutable ways to gain and exercise power, to break existing dominance and to open space for self-updating and fulfilment. In brief, research is a legitimate means of empowering teachers in the twenty-first century.
The theoretical considerations presented in this article suggest that it is worth integrating teaching and research to help develop and empower teachers professionally. This integration, however, requires a type of research whereby teachers can search for solutions to real everyday problems and look for ways to transform the educational establishment. I, therefore, encourage teachers to resort to AR so that teaching, research, learning and self-updating can take place in their classroom practices and circumstances. Rightly, Martin Parrot (1996, p. 3, cited in Madrid, 2000) defined AR as:

...not so much something that we do in addition to our teaching, as something that we integrate into it. In many ways, it is a state of mind - it is scepticism about assumptions and a willingness to put everything to the test... It is a way of ensuring that we continue to learn even as we teach. It helps to stave off staleness and routine.

\section{References}

ACOSTA, R. (2006). "Formación de profesores en el paradigma de la complejidad.” Educación y Educadores, 9(1), 149157. Available at http://educacionyeducadores.unisabana.edu.co/index.php/eye/article/view/653/738 (accessed on 28 April 2010).

ALLWRIGHT, R. and BAILEY, K. (1981). Focus on the language classroom. Cambridge: Cambridge University Press.

AGUIRRE-GARCÍA, J. and JARAMILLO-ECHEVERRI, L. (2008). "Consideraciones acerca de la investigación en el aula: más allá de estar a la moda." Educación y Educadores, 11(1), 43-54. Available at http://educacionyeducadores.unisabana.edu.co/index.php/eye/article/view/717/800 (accessed on 28 April 2010).

BABBIE, E. (1983). The Practice of Social Research (3rd ed.). Belmont, CA: Wadsworth.

BAHKTIN, M. (1986). Speech Genres \& Other Late Essays edited by C. Emerson \& M. Holquist. Austin: University of Texas Press.

BECERRA, C. (2005). “Teacher voice: How is it shaped?” Colombian Applied Linguistics Journal, 7, 43-52. Available at http://calj.udistrital.edu.co/pdf_files/App_2005/Art3.pdf (accessed on 28 April 2010).

BLOLAND, P. (1992). Qualitative Research in Student Affairs. ERIC Clearinghouse on Counseling and Personnel Services. Ann Arbor: MI. 
CALVO, G. (2003). "El docente: Responsable de la investigación pedagógica.” In: Experiencias docentes, calidad y cambio escolar, R. Cortes Salcedo, M. E. Romero, H. Sarmiento, J. Vargas, E. Torres, \& A. Uson, 97-105. Bogotá: Ed. Grupo Editorial Gaia. ISBN: 9588066298. Available at http://www.lablaa.org/blaavirtual/educacion/expedocen/ expedocen5c.htm (accessed on 28 April 2010).

CÁRDENAS, M. (2000). “Action Research by English Teachers: An Option to Make Classroom Research Possible." Colombian Applied Linguistics Journal, 2 (1), 15-26. ISSN 0123-4641.

COCHRAN-SMITH, M. and LYTLE, S. L. (2001) “Beyond certainty: Taking an inquiry stance on practice.” In: Teachers Caught in the Action: Professional Development that Matters, edited by A. Lieberman, \& L. Miller. New York: Teachers College Press.

CONTRERAS, J. (2001) La autonomía del profesorado. Madrid: Ediciones Morata, 2001.

CORTÉS, L., HERNÁNDEZ, J. and ARTEAGA, R. (2008). “¿Qué espera la sociedad colombiana de los profesores de lenguas extranjeras?". Revista Electrónica Matices en Lenguas Extranjeras, 2, 19-32 Available at http://www.revistamatices.unal.edu.co/pdfs/02Cortes.pdf (accessed on 28 April 2010).

CuMminS, J. (1994). Knowledge, Power and Pedagogy. Bilingual Children in the Crossfire. Clevedon: Multilingual Matters.

DUFEU, B. (1994). Teaching Myself. Oxford: Oxford University Press.

ELLIOT, J. (1994). La Investigación acción en educación. Madrid: Ediciones Morata.

FINCH, A. (2005). “Action Research: Empowering the Teachers.” Pleiades: Journal of Teaching Young Learners of English, 1(1), 30-48. Available at http://www.eslteachersboard.com/cgi-bin/articles/index.pl?read=950 (accessed on 28 April 2010).

FRODDEN, C. (1999, January ). “Action Research in a Graduate Foreign Language Teaching Program.” Íkala: revista de lenguaje y cultura, 4(7-8), 101-124. Available at http://quimbaya.udea.edu.co/ikala/images/PDFs/art7_vol4.pdf (accessed on 28 April 2010).

FOUCAULT, M. (1972). Archaeology of knowledge. New York: Pantheon.

GLATTHORN, A. (1995). “Teacher Development.” In: International Encyclopedia of Teaching and Teacher Education, edited by L. Anderson (2nd edition). London: Pergamon Press.

HERNÁNDEZ, I. (2009). "El docente investigador en la formación de profesionales." Revista Virtual Universidad Católica del Norte, May-August o, 27, 1-21, ISSN 0124-5821. Available at http://revistavirtual.ucn.edu.co/index. php?option=com_content\&task=view\&id=84\&Itemid=1 _(accessed 28 April 2010).

INGVARSON, L. (1998). "Professional Development as the Pursuit of Professional Standards: The Standard-based Professional Development System." Teaching and Teacher Education, 14(1), 409-418. Available at http://works. bepress.com/lawrence_ingvarsonl/66/(accessed 29 June 2009).

KEMMIS, S. (1993). “Action Research and Social Movement: A Challenge for Policy Research.” Education Policy Analysis Archives, 1(1) ISSN 1068-2341. Available at http://epaa.asu.edu/ojs/article/viewFile/678/800 (accessed 28 April 2010). 
LOCASTRO, V. (2000). “Teachers Helping Themselves: Classroom Research and Action Research.” The Language Teacher, 94. Available at http://www.jalt-publications.org/tlt/files/94/feb/locastro.html (accessed 28 April 2010).

MADRID, D. (2000). “Observation and Research in the Classroom.” Teaching English as a Foreign Language, Barcelona: The Australian Institute, 1-39. [Consulted on 30 June 2009] Available at http://www.ugr.es/ dmadrid/ Publicaciones/Learning\%20Strategies.htm (accessed 28 April 2010).

MARTÍNEZ, M. (2008). "Innovar e investigar: dos modos de visibilizar el posicionamiento y empoderamiento del docente." Magazin Aula Urbana, 65, 3, ISSN 0123-4242. Available at http://issuu.com/idep/docs/aulaurbana65 (accessed 28 April 2009).

MCKERNAN, J. (1996). Curriculum Action Research. A Handbook of Methods and Resources for the Reflective Practitioner (2nd ed.). London: Kogan, 1996.

MCNIFF, J. (2002) Action Research for Professional Development: Concise -Advice for New Action Researchers [online]. Available at http://www.jeanmoniff.com/bookletl.html (accessed 28 April 2010).

MEJÍA, A. (1999). Teacher Empowerment: A Challenge for the Twenty-first Century. How: A Colombian Journal for English Teachers, 10(16). ISSN: 0886-0483.

NUNAN, D. (1989). Understanding Language Classrooms: A Guide for Teacher-initiated Action. UK: Prentice Hall International.

O'BRIEN, R. (2001). “An Overview of the Methodological Approach of Action Research.” In: Theory and Practice of Action Research edited by R. Richardson. João Pessoa, Brazil: Universidade Federal da Paraíba, 19 p. (English version). Available at http://www.web.ca/ robrien/papers/arfinal.html (accessed on 28 April 2010).

PAGE, N. and CZUBA, C. (1999). "Empowerment: What Is It?" Journal of extension, 37(5) ISSN 1077-5315. Available at http://www.joe.org/joe/1999october/comml.php (accessed on 28 April 2010).

PARRA, C. (2002). "Investigación acción y desarrollo profesional." In: Educación y educadores, 5, 113-125. Available at http://educacionyeducadores.unisabana.edu.co/index.php/eye/article/view/515/1602 (accessed on 28 April 2010).

PARROT, M. (1996). Tasks for Language Teachers: A Resource Book for Training and Development. UK: Cambridge University Press.

QUINTERO, J., MUNEVAR, R. and YEPES, J. C. (2007). "Investigación-Acción y Currículo: Un Recorrido por el Mundo." Revista Latinoamericana de estudios educativos, 3(1), 123-142. Available at http://latinoamericana.ucaldas. edu.co/downloads/Latinoamericana3-1_8.pdf (accessed on 28 April 2010).

QUINTERO, J., ZULIA, C. and RAMÍREZ, O. (2005). "Being and Becoming Researchers.” Revista Latinoamericana de Estudios Educativos, 1, 148-159. Available at 200.21.104.25//atinoamericana/downloads/Latinoamericanal_8.pdf (accessed on 28 April 2010).

RESTREPO, B. (1999). "Maestro investigador, escuela investigadora e investigación.” Cuadernos Pedagógicos, 14, 97116. Medellín: Universidad de Antioquia.

RESTREPO, B. (2003). “Aportes de la investigación-acción educativa a la hipótesis del maestro investigador: evidencias y obstáculos.” Educación y Educadores, 6, 91-104. Available at http://educacionyeducadores.unisabana.edu.co/ index.php/eye/article/view/529/622 (accessed on 28 April 2010). 
RESTREPO, B. (2004). "La investigación-acción educativa y la construcción de saber pedagógico." Educación y Educadores, 7, 45-55. Available at http://educacionyeducadores.unisabana.edu.co/index.php/eye/article/view/548/641 (accessed on 28 April 2010).

ROMANISH, B. (1993). "Teacher Empowerment as the Focus of School Reforming." The School Community Journal, 3(1), 47-60. Available at http://www.adi.org/journal/ss93/RomanishSpring1993.pdf (accessed on 28 April 2010).

SÁNCHEZ, A. (2002). "Dispositivos de empoderamiento para el desarrollo psicosocial." Univ. Psychol, 1(2), 39-48, Bogotá (Colombia). Available at http://sparta.javeriana.edu.co/psicologia/publicaciones/actualizarrevista/archivos/ V1N205dispositivos_empoderamiento.pdf (accessed on 28 April 2010).

SARAC-SUZER, H. (2007). “Action Research.” Karen’s linguistics issues, February [online]. Available at http://www3. telus.net/linguisticsissues/actionresearch (accessed on 28 April 2010).

SHORT, P. (1994). “Defining Teacher Empowerment." Education, 114(4), 488-492. Available at http://findarticles. com/p/articles/mi_qa3673/is_n4_v114/ai_n28646672/ (accessed on 28 April 2010).

STENHOUSE, L. (1975). An Introduction to Curriculum Research and Development. London: Heinemann Educational.

STENHOUSE, L. (1993). La investigación como base de la enseñanza. Madrid, Ediciones Morata.

USMA, J. (2007). “Teacher Autonomy: A Systematic Review of the Concept Beyond Applied Linguistics.” Íkala: Revista de lenguaje y cultura, 12(18), 245-275. Available at http://quimbaya.udea.edu.co/ikala/images/PDFs/Vol\%20 12\%20articulo\%2010.pdf (accessed on 28 April 2010).

VAN LIER, L. (1988). The Classroom and the Language Learner. Ethnography and Second Language Classroom Research. Harlow: Longman.

VERGARA, O., HERNÁNDEZ, F. and CÁRDENAS, R. (2009). "Classroom Research and Professional Development". PROFILE, 11, 169-191. Available at http://www.revistas.unal.edu.co/index.php/profile/article/view/10557/11017 (accessed on 28 April 2010).

VILLEGAS-REIMERS, E. (2003). Teacher Professional Development: An International Review of the Literature. Paris: IIEP UNESCO. Available at http://unesdoc.unesco.org/images/0013/001330/133010e.pdf (accessed on 28 April 2010).

WHITEHEAD, J. (1989). "Creating a Living Educational Theory from Questions of the Kind, How do I improve my practice?" Cambridge Journal of Education, 19(1), 41-52. Available at http://www.actionresearch.net/writings/livtheory. html (accessed on 28 April 2010).

ZIMMERMAN, M.A. and RAPPAPORT, J. (1988). "Citizen Participation, Perceived Control, and Psychological Empowerment.” American Journal of Community Psychology, 16(5), 725-750. 